\title{
Efficient Compost Fertilizer with Addition of Fatty Acid Results of Used Cooking Oil Saponification Reaction
}

\author{
Aprilia Dewi Ardiyanti ${ }^{1, *}$, Lukman Adhitama ${ }^{2}$, Rina Wahyutiyani ${ }^{3}$ \\ ${ }^{1}$ Physic Department, ${ }^{2}$ Industrial Engineering Departement, ${ }^{3}$ Physic Education Departement, Faculty of Science and Technology, \\ UIN Sunan Kalijaga Yogyakarta, Jl. Marsda Adisucipto No 1 Yogyakarta 55281, Indonesia. Tel. +62-274-589621, Fax. +62-274-586117. \\ Email*: apriliadewi379@gmail.com
}

\begin{abstract}
The development of the times accompanied by technological developments have brought humans to the Post Modern era. The industry is growing rapidly in all lines, both from the sectors of production of goods, textiles, materials and even penetrated the food sector. Food innovations have sprung up rapidly and creating waste. One of them is vegetable and fruit waste. However, this waste can be processed into compost because the content of Nitrogen, Phospor and Potassium (NPK) which is a basic need for plants to carry out photosynthesis. Processing of vegetable waste into compost is done by adding EM4, molasses and remaining rice washing water. Fermentation is carried out for four weeks to produce compost. Other waste arises from the food industry which produces foodstuffs by frying. Used cooking oil left over from the frying pan is often discharged into the environment to cause pollution. This can be more severe if the disposal is in residential areas. Saponification reaction using natrium hydroxide $(\mathrm{NaOH})$ can separate glycerol and fatty acids from used cooking oil. Fatty acids from the separation of solid waste cooking oil can purify the NPK content in compost, so that when mixed with compost an efficient compost can be produced and has a high NPK percentage. The purpose of this study is to obtain accurate information from literature studies to determine the percentage of NPK in compost after adding fatty acids from used cooking oil.
\end{abstract}

Keywords: Compost, fruit-vegetable waste, NPK, saponification reaction, used cooking oil

\section{INTRODUCTION}

In this Post Modern era, life goes very dynamic. All lines of life go very fast. Problems are increasingly becoming complex, such as the problem of garbage. In Indonesia, the amount of waste produced every day in each region is not less than 300 tons per day. The amount is very fantastic and when associated with the balance of nature, that number will cause an imbalance in nature. Three hundred tons of waste is a mixture of organic waste and non-organic waste (Alex, 2011).

Nowadays the use of chemical fertilizers is increasingly used, most of the farmers use chemical fertilizers in farming. Chemical fertilizers do have a very good effect on the initial application, but if given sustainably and in large portions will have a negative impact on the soil. The soil will be more acidic and lose its fertility due to the provision of chemical nitrogen and other elements. The physical properties of the soil deteriorate, the soil becomes dense, phosphate accumulation occurs, the soil micro-biological conditions are less harmonious so that the activities of the soil microorganisms decline. Fruit-vegetable waste into compost is processed first with a series of fermentation. The vegetable waste is initially cut so that the size gets smaller and accelerates decomposition, then mixed with EM4, molasses and water left over from washing rice. EM4 is a bacterium that will be active if stimulated in the form of other compounds and in this case fruit-vegetable waste, while molasses is a solution of brown sugar. After all the ingredients are mixed, the ingredients are put into a fermentation bucket, about four weeks there will be fermentation and compost is formed (Purnawati, 2016).

Besides the problem of vegetable waste, the use of cooking oil in life has dominated cooking. As a result, used oil will be created or known as used cooking oil. Used cooking oil can be recognized from the smell, color and appearance. When the oil has turned brown, thick and rancid, the oil has been included in the definition of used cooking oil. These properties are caused by decomposition of fatty acids and due to reactions at high temperatures (La Ode, 2018).

Fatty acids mixed with compost can purify the NPK content so that compost fertilizer which has a higher percentage of NPK is obtained than ordinary compost fertilizer. Fatty acids from used cooking oil can be produced through saponification reaction.

Saponification reaction is hydrolysis reaction of fats or oils using strong bases such as $\mathrm{NaOH}$ and $\mathrm{KOH}$ to produce glycerol and fatty acids. The saponification reaction produces glycerol which is a carbon and hydrogen bonding group. Glycerol has very strong bonds that are very difficult to break down. The second result of the saponification reaction is fatty acids. The fatty acids resulting from the reaction can be used to purify the NPK content in compost. Fatty acids in the form of solids added to compost after fermentation and compost will react and increase the efficiency of compost by increasing the percentage of NPK. 


\section{MATERIALS AND METHODS}

This type of research is qualitative and quantitative research using the object of research studies in the form of journals and books concerned so that this research is also library research. The purpose of the study of literature in this paper is as a basis for forming the initial writing plan and as a secondary source of writing data. Literature method is done by collecting data, processing data and analysing data. While the problem was raised through a field survey at the Beringharjo Market in Yogyakarta and a cassava flake factory in Magelang.

Data collection techniques are carried out through several stages. The first stage is a preliminary study, which determines the background of the problem so as to come up with a solution. The second stage is the identification and formulation of the problem. The third stage is literature study and the last is data collection, so accurate information is obtained to present solutions to the problems that have been identified.

Data processing techniques are carried out using data that has been collected to determine a number of things, including the manufacture of compost fertilizer combined with used cooking oil. The first step is to determine the content contained in used cooking oil and then determine how to separate fatty acids and glycerol from used cooking oil with the help of $\mathrm{NaOH}$. While for compost is knowing the best mix of fruit vegetable waste ingredients to make compost, then combining it with fatty acids to obtain a purer NPK content. the last part is finding ways to calculate the percentage of NPK in compost after mixing, so that accurate data information is obtained about how to make compost fertilizer efficiently.

The data analysis technique used in this research is content analysis. The analysis is done by comparing the sources of literature as a result of processing data, facts and information. Also compared between relevant data and theory. With this kind of analysis is expected to be able to and choose data from a variety of existing library materials and in line with the object of study in question and can produce a more objective and systematic description.

\section{RESULTS AND DISCUSSION}

\section{Potential of fatty acids as a result of saponification reaction to produce more efficient compost fertilizer}

Used cooking oil is a used frying oil that has changed its color, odor and viscosity, which if it is still used sustainably will cause adverse effects on health. Until now, waste cooking oil waste processing is still very minimal and most of the waste is just thrown into the environment. Used cooking oil which is discharged into the environment without prior processing can cause adverse impacts on the environment both for aquatic ecosystems and terrestrial ecosystems.
Utilization of used cooking oil that has been carried out so far is by processing it into biodiesel fuel. But the reality in the field is because it requires quite sophisticated technology and a sizable cost so that not many people use waste cooking oil for diesel fuel. Therefore, an innovation is needed to utilize waste cooking oil with a simple process that does not require a large cost.

Utilization of used cooking oil as a purification of the percentage of NPK in compost fertilizer is an economical choice because compost produced has a low NPK content. The majority of Indonesia's population are farmers who are very dependent and in need of fertilizer, besides that compost houses that have been established in markets and villages have become a separate opportunity. So that the use of compost from vegetable waste with waste cooking oil becomes an interesting alloy.

Used cooking oil which has a composition of fat and oil when reacted with a strong base with low molarity, it will form two compounds namely fatty acids and glycerol. This reaction is called the saponification reaction.

In the manufacture of PUKOSIEN $0.1 \mathrm{~mol} \mathrm{NaOH}$ is used, with a moderation that is not too high causing the fatty acids produced in the form of liquid. One reacted fat will produce three fatty acids and glycerol. Basically, the percentage of NPK used is purification of fatty acids, but because the ratio between the amount of fatty acids and glycerol is very significant coupled with the molar mass ratio of fatty acids that are much larger than glycerol, the amount of glycerol can be ignored (La Ode, 2018).

Fatty acids are hydrocarbon-derived compounds, carboxylic acids. Hydrocarbon compounds are compounds that have many carbon chains (C) which are elements of group IV A which have as many as 4 valence electrons. Valence electrons, which are 4, make it possible for element $\mathrm{C}$ to hold other elements to reach a stable state (octet), so that hydrocarbon compounds have easily bound to other compounds. Because fatty acids are part of carboxylic acids so they have easy binding properties.

The bonding properties are useful when reacted and combined with compost. The elements $\mathrm{N}, \mathrm{P}$ and $\mathrm{K}$ which are in the prospective compost vegetable waste can be bonded properly and optimally. This fact can be a solution to the current problem of compost that has low NPK levels. The combination of fatty acids from cooking oil saponification with compost into fresh air and solutions to the problem of waste and fertilizer (Herlina, 2002).

\section{Making liquid compost fertilizer}

Compost is the result of incomplete decomposition of a mixture of organic materials that can be accelerated by populations of various microbes in warm, humid and aerobic or anaerobic conditions. In the manufacture of 
liquid compost, aerobic composting is used in which in the composting process air is needed. In order to obtain liquid compost, materials such as organic market waste, EM4 (effective Microorganism 4), molasses (sugar cane drops) and rice washing water are needed. The tools used are composter buckets arranged in such a way. The composter bucket consists of used paint bucket, paralon, strimin as a filter between solid and liquid fertilizer and water faucet as a regulator of the flow of liquid compost (Sudiana, 2010).

Given the length of time required for aerobic composting (40-50 days) it is necessary to find an alternative solution for composting. The way to speed up the composting process is to use an activator. EM4 (effective Microorganism 4) is a mixed culture of microorganisms used as a starter to increase the diversity and population of microorganisms. The content of microorganisms contained in EM4 include photosynthetic bacteria (Rhodopseudomonas sp), lactic acid bacteria (Lactobacillus sp), yeast (Saccharomyces sp) and fermented fungi (Aspergillus and Penicilium). The bacteria in EM4 get their nutrients from mollases which are diluted with rice washing water. With the addition of EM4 in the process of making compost using the aerobic bucket method, it will be 1-2 weeks faster than conventional methods (Lulu, 2015).

The ways of making compost are as follows:

1. Prepare a composter bucket, which functions as a container for making compost

2. Cutting fruit vegetable waste into smaller pieces which is useful for accelerating the composting process

3. Mix the mixture of EM4, molasses (sugar cane drops) and rice washing water on the fruit vegetable waste slices evenly

4. Inserting fruit vegetable waste into the composter bucket until it is full, this is intended to obtain liquid compost in greater amounts.

5. Close the composter bucket and drain valve, so that the composterization process goes well and the liquid compost fertilizer is not wasted.

6. Wait for the composter process 3-4 weeks to get liquid compost with a greater amount (Akil, 2013; Latifah, 2012).

\section{Reaction of fatty acids and compost fertilizers into PUKOSIEN}

Saponification reaction produces fatty acids and glycerol in liquid form because the base used has a low polarity. The fatty acids will be mixed in compost fertilizer which has been fermented for four weeks. The mixing process is done by mixing evenly between the liquid compost fertilizer and the fatty acid liquid. Stirring and mixing aim to interact between fatty acids and salinf compost liquid and NPK binding occurs so that PUKOSIEN has a high level of efficiency.

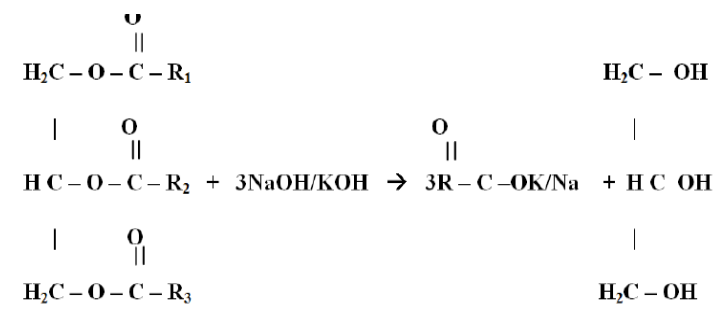

Figure 1. Saponification reaction.

Testing the percentage of NPK on efficient compost The percentage of NPK from efficient compost can be known by using a device called an NPK Tester. There are several procedures in NPK testing such as mixing PUKOSIEN samples with other compounds before measuring the percentage. Through chemical calculations and taking into account the calibration factor of the NPK Tester the percentage of N, P and $\mathrm{K}$ in compost fertilizer can be known efficiently (Deffy and Enang, 2015).

\section{Analysis of NPK levels required for plants}

Efficient compost in scientific papers is an innovation from compost that is familiar in the community at large. Usually, the compost is produced through organic waste both from leftover vegetables and fruits. The waste is then processed through certain stages so that it becomes compost. In a study conducted by Latifah (2012) it was said that the levels of $\mathrm{N}, \mathrm{P}$ and $\mathrm{K}$ in compost with market waste materials were $0.16 \%, 0.014 \%$ and $0.25 \%$, respectively (Santoso, 2015). The N, P and K requirements of some plants are presented in the Table 1.

Table 1. The N, P and K requirements of some plants.

\begin{tabular}{llll}
\hline PLANTS & $\begin{array}{l}\text { NITROGEN } \\
(\mathbf{N})\end{array}$ & $\begin{array}{l}\text { FOSFOR } \\
(\mathbf{P})\end{array}$ & $\begin{array}{l}\text { KALIUM } \\
(\mathbf{K})\end{array}$ \\
\hline Corn & $2.19 \%$ & $0.49 \%$ & $1.96 \%$ \\
Tomato & $3.83 \%$ & $0.23 \%$ & $1.85 \%$ \\
Mustard greens & $3.00 \%$ & $0.35 \%$ & $3.50 \%$ \\
\hline
\end{tabular}

From these data it can be seen that there is a large gap between the needs of the elements $\mathrm{N}, \mathrm{P}$ and $\mathrm{K}$ needed by plants with levels of $\mathrm{N}, \mathrm{P}$ and $\mathrm{K}$ present in compost produced by processing fruit-vegetable waste. This shortage of NPK needs can be supplied by PUKOSIEN due to the binding of NPK elements obtained from waste cooking oil saponification so that the level of adequacy achieved is greater (Akil, 2013).

\section{CONCLUSIONS}

The first step in making Efficient Compost Fertilizer is to process used cooking oil with saponification reaction so that used cooking oil turns into fatty acids and glycerol. The results of the reaction are then mixed with 
a stirring technique with fermented liquid compost for 4 months. After the two ingredients are mixed, the NPK content in Efficient Compost Fertilizer can be calculated with the NPK Tester.The superiority of Efficient Compost Fertilizer compared to other compost fertilizers is the independent variable of the addition of fatty acids from the saponification reaction. Fatty acids that have carbon chain groups make it easy to bond with other compounds, so the NPK content in compost can be bonded perfectly. This makes the NPK content in Efficient Compost Fertilizer higher than ordinary compost. These advantages can be further applied to certain plants and soil conditions.

\section{REFERENCES}

Akil M. 2013. Kebutuhan Hara N, P, dan K Tumbuhan Jagung Hibrida pada Lahan Kering di Kabupaten Goa. Balai Penelitian Tanaman Serealia.

Alex S. 2011. Sukses Mengolah Sampah Organik Menjadi Pupuk Organik. Pustaka Baru Press, Yogyakarta.
Deffy, Enang. 2015. Simulasi Aplikatif Pembuatan Pupuk Organik Cair dan Kompos pada BPLH Majalengka. Infotech Journal 1: 12-17.

Herlina, Netti, Hendra G. 2002. Lemak dan Minyak. USU Digital Library, Sumatera Utara.

La Ode, Lela M, Ratna I. 2018. Analisis Mutu Minyak Jelantah Hasil Peremajaan Menggunakan Tanah Diatomit Alami dan Terkalsinasi. Universitas Muhammadiyah Sukabumi, Sukabumi.

Latifah RN. 2012. Pemanfaatan Sampah Organik Sebagai Bahan Pupuk Cair Untuk Pertumbuhan Tanaman Bayam Merah (Alternanthera ficoides). LenteraBio 1: 3-10.

Lulu N, et al. 2015. Pengolahan Limbah Sayur Kol menjadi Pupuk Kompos dengan Metode Takakura. Infotech Journal 2: 17-56.

Purnawanti, Bagyono, Fauzy. 2016. Pemanfaatan Sampah Buah dan Air Cucian Beras Menjadi Pupuk Kompos. Jurnal Kesehatan Lingkungan 7: 193-198.

Santoso B. 2005. Pengaruh Bahan Organik dan Pupuk NPK Terhadap Hasil Serat Rosella di lahan Podsolik Merah Kuning Kalimantan Selatan. Jurnal Littri 11: 85-92.

Sudiana E. 2010. Cara Pembuatan Kompos. Fakultas Biologi UNSO. Purwakarta 